ORIGINAL ARTICLE

\title{
Fine mapping of a region on chromosome 21q21.11- q22.3 showing linkage to type 1 diabetes
}

\author{
R Bergholdt, J Nerup, F Pociot
}

J Med Genet 2005;42:17-25. doi: 10.1136/jmg.2004.022004

See end of article for authors' affiliations .....................

Correspondence to: Dr Flemming Pociot, Steno Diabetes Centre, 2 Niels Steensensvej, DK-2820 Gentofte, Denmark; fpoc@ steno.dk

Revised version received 23 July 2004 Accepted for publication 5 August 2004
Background: Results of a Scandinavian genome scan in type 1 diabetes mellitus (TID) have recently been reported. Among the novel, not previously reported chromosomal regions showing linkage to T1D was a region on chromosome 21 .

Objective: To fine map this region on chromosome 21.

Methods and results: The linked region was initially narrowed by linkage analysis typing microsatellite markers. Linkage was significantly increased, with a peak NPL score of 3.61 ( $p=0.0002$ ), suggesting the presence of one or several TID linked genes in the region. The support interval for linkage of 6.3 Mb was then studied by linkage disequilibrium (LD) mapping with gene based single nucleotide polymorphisms (SNPs). Thirty two candidate genes were identified in this narrowed region, and LD mapping was carried out with SNPs in coding regions (cSNPs) of all these genes. However, none of the SNPs showed association to TID in the complete material, whereas some evidence for association to TID of variants of the TTC3, OLIG2, KCNE1, and CBR1 genes was observed in conditioned analyses. The disease related LD was further assessed by a haplotype based association study, in which several haplotypes showed distorted transmission to diabetic offspring, substantiating a possible T1D association of the region.

Conclusions: Although a single gene variant responsible for the observed linkage could not be identified, there was evidence for several combinations of markers, and for association of markers in conditioned analyses, supporting the existence of TID susceptibility genes in the region.
$\mathrm{T}$ ype 1 diabetes mellitus (T1D) [MIM 222100] is caused by an immune mediated destruction of the insulin producing $\beta$ cells in the pancreas. $\beta$ Cell destruction is irreversible and despite intensive insulin therapy the condition is connected with development of late diabetic complications and increased mortality. ${ }^{1}$ TID is characterised as a complex genetic disease, with multiple genetic loci and environmental factors involved. The main part of the genetic risk for TID is conferred by the HLA region, but several "minor" loci are likely to be involved (reviewed by Pociot and McDermott ${ }^{2}$ ).

We have recently reported results of a Scandinavian genome scan in TID comprising 464 affected sibling pairs from Denmark, Sweden, and Norway. ${ }^{3}$ Previously published T1D loci were evaluated and new regions showing linkage to TID were identified. Among the new, not previously reported chromosomal regions showing linkage to TID was a region on chromosome $21 .^{3}$ This region mapped to the distal part of chromosome 21 (21q21.3-qTel) and revealed some evidence for linkage to TID, with a maximum LOD score of 1.23 $(\mathrm{p}=0.009)$ and a non-parametric linkage (NPL) score of 1.97 $(p=0.02)$. Linkage was most evident in the Danish population, where a maximum LOD score of $2.33(\mathrm{p}=0.009)$ was obtained, with an NPL score of $2.64 \quad(p=0.004)$. Furthermore, interaction analyses have recently given additional support to this region as being important in TID. In a combined neural network-decision tree analysis of Danish and Swedish TID genome scan data, this region on chromosome 21 was also identified. ${ }^{4}$

The linked region on chromosome 21 comprised approximately $20 \mathrm{Mb}$, which equals about $35 \mathrm{cM}$ (www.ncbi.nlm. nih.gov/genemap). The complete sequence of chromosome 21 is known and 225 genes have been identified on this chromosome. ${ }^{5}$ The existence of the complete sequence of this chromosome means that new strategies for identification of genes are applicable instead of classical positional cloning.
Furthermore the position of genes, microsatellites, and sequence variations can be identified.

The distal part of chromosome 21 harbours a few established candidate genes for autoimmunity, including TID. The AIRE gene (21q22.3) encodes a regulator of transcription, in which mutations have been shown to give rise to the disease APECED (autoimmune poly-endocrinopathy-candidiasis-ectodermal dystrophy). ${ }^{6-8}$ APECED is a rare systemic autoimmune disorder of monogenic and autosomal recessive inheritance. ${ }^{9}$ Another gene is CBRI (21q22.12). Our group has carried out proteome analysis of interleukin $1 \beta$ (IL$1 \beta$ ) exposed, diabetes-prone, Bio Breeding (BB-DP) rat islets of Langerhans in vitro. ${ }^{10}$ We showed that the protein carbonyl reductase 1 (CBRl), encoded by the CBRl gene, is downregulated fivefold by IL- $1 \beta$ exposure. As IL- $1 \beta$ is believed to be an important cytokine involved in destruction of the $\beta$ cell, ${ }^{11}$ this finding suggests a role for CBRI in TID pathogenesis. Cu/Zn superoxide dismutase l (SOD1) (21q22.1), which is a potent antioxidant, has also been implicated in genetic predisposition to alloxan induced diabetes in mice. ${ }^{12}{ }^{13}$

The runt related transcription factor 1 (RUNX1) (21q22.3), also called $A M L 1$, is another candidate gene for autoimmunity, including TID. Recently, reports in three other autoimmune diseases-systemic lupus erythematosus, psoriasis, and rheumatoid arthritis-have demonstrated disease associated mutations in RUNXl binding sites of three different genes. ${ }^{14-16}$ However, in rheumatoid arthritis an intron 6 single nucleotide polymorphism (SNP) in the

\footnotetext{
Abbreviations: APECED, autoimmune poly-endocrinopathycandidiasis-ectodermal dystrophy; cSNP, single nucleotide polymorphism in coding region; IL-1, interleukin 1; LD, linkage disequilibrium; LOD, log of odds ratio; NPL, non-parametric linkage; Sib-TDT, sibling transmission disequilibrium test; SNP, single nucleotide polymorphism; TDT, transmission disequilibrium test; T1D, type 1 diabetes
} 
RUNXI gene itself also showed disease association in a casecontrol study. ${ }^{14}$

On the basis of this combined information, we therefore believe that the rationale for fine mapping of the linked region is solid.

\section{METHODS \\ DNA}

We used DNA from 253 Danish T1D families (1097 individuals), comprising 155 sibling pair families and 98 simplex families. ${ }^{3}{ }^{17}$ For the initial linkage mapping, the 155 sibling pair families were used, whereas the subsequent linkage disequilibrium (LD) mapping included all the families. All probands were aged below 30 years at onset, and diagnosis of TID was according to WHO criteria. Median age at onset was nine years.

\section{Genotyping and linkage analysis of microsatellites}

The microsatellites chosen were all dinucleotide repeats, and preferably the ones with the highest heterozygosity covering the region of interest most evenly. The markers were chosen based on the Marshfield map. Typing of microsatellites was done by polymerase chain reaction (PCR) amplification of marker sequences, using fluorescently labelled primers, followed by analysis of the fragments on automated DNA sequencing equipment (ABI Prism 3100, Applied Biosystems, Foster City, California, USA). Collection and analysis of data involved the software programs GeneScan, GenoTyper, and GeneMapper, while the multipoint NPL analysis and calculation of information content level of markers was carried out using the program GeneHunter version 1.2. ${ }^{18}$ Marker order and intermarker distances were based on the physical map of chromosome 21 .

\section{Genotyping and analysis of SNPs}

We identified all SNPs in coding regions (cSNPs) of the identified candidate genes, listed in dbSNP (NCBI), build 116. PCR primers were selected from the available sequences surrounding the mutations, and PCR products of 300 to 500 nucleotides in length were amplified. Single base primer extension reactions with primers terminating one nucleotide before the mutations were designed for each cSNP and employed for screening. We used the SnapShot Multiplex kit (Applied Biosystems) and automated DNA sequencing equipment (ABI prism 3100, Applied Biosystems). All SNPs were screened in 96 patients with TID, and only SNPs with a frequency of the rarest allele of more than 3\% were used for further analysis. The limit of 3\% was set because these SNPs are believed to be common enough to have potential significance. The SNPs selected for further analysis were genotyped in the complete material of 253 Danish TID families (1097 individuals). Depending on which technique yielded the best results, typing of the complete material was carried out by a PCR based restriction fragment length polymorphism (RFLP) assay or mutagenically separated (MS)-PCR, or otherwise by the SnapShot (primer extension) reaction.

\section{Testing for linkage in the presence of linkage disequilibrium}

Multiplex and simplex families were tested for linkage in the presence of linkage disequilibrium by Sib-TDT (sibling transmission disequilibrium test). ${ }^{19}$ Subgroup analyses of families showing linkage and not showing linkage, respectively, were also done by Sib-TDT. Division of families with and without evidence of linkage was undertaken by evaluating the multipoint NPL score for each family at the position showing the maximum NPL score in the complete material. Families with evidence of linkage were defined as those with
NPL scores above 1.00 (maximum score, 1.41). Analysis of transmissions of haplotypes was by the transmission disequilibrium test (TDT), using the GeneHunter software.

\section{Pairwise linkage disequilibrium measurements}

Parental (founder) haplotypes for microsatellites and genotyped SNPs in the $6.3 \mathrm{Mb}$ linked region were estimated by maximum likelihood estimates, using GeneHunter vs 1.2. HaploXT (http://archimedes.well.ox.ac.uk/pise/haploxt-simple. $\mathrm{html}$ ) to calculate pairwise $\mathrm{LD}$ indices ( $\mathrm{D}^{\prime}$ values). $\mathrm{LD}$ values above 0.5 were defined as the threshold for LD.

\section{RESULTS}

\section{Linkage analysis}

Thirty five microsatellite markers covering the $20 \mathrm{Mb}$ region of interest were identified and typed in 155 sibling pair families. Seven of the 35 markers were included in the original genome scan. ${ }^{3}$ Data from the 35 markers were used in a multipoint NPL analysis (fig 1). The multipoint NPL analysis showed a significantly increased $z$ value, with a peak NPL score corresponding to marker D21S1920 of 3.61 $(p=0.0002)$. A $6.3 \mathrm{Mb}$ region was identified as the "one LOD drop" interval, showing NPL scores above 2.61 (table 1). The information content level of the region of interest was between $95 \%$ and $100 \%$ (GeneHunter, version 1.2 ), based on data from the 35 markers (not shown). Thus it was not possible to narrow the region further by linkage analysis in the current families.

\section{Linkage disequilibrium mapping}

We have chosen a strategy of analysing the 32 identified positional candidate genes in order to characterise the region further and search for one or more aetiological mutations responsible for the demonstrated linkage of this region to TID. The identified genes were examined by typing known cSNPs, identified from the dbSNP, build 116 (SNP database at NCBI, National Center for Biotechnology Information), in order to identify aetiological mutations or SNPs in linkage disequilibrium with a close by aetiological TID mutation. In the 32 genes, 74 coding SNPs were identified. All 74 SNPs have been screened in 96 unrelated diabetic patients and only SNPs with a minor allele frequency above 3\% were further genotyped and analysed for TID association in the complete material of 253 TID families. For a substantial number of SNPs no carriers were detected when screening 96 TID individuals, questioning the relevance of these SNPs in the Danish population.

None of the SNPs analysed showed significant linkage, in the presence of linkage disequilibrium, to TID (table 2). For one SNP, rs2154538-in exon 19 of the tetratricopeptide repeat domain 3 gene (TTC 3 ) - a distorted transmission of the alleles to unaffected offspring was observed: 108 transmissions $v \quad 81$ non-transmissions $(\mathrm{p}=0.0495$; uncorrected p value). Additionally, for rs2835655 in exon 39 of TTC3, a borderline significant distortion was found in the Sib-TDT: 119 transmissions $v 150$ non-transmissions $(\mathrm{p}=0.057$; uncorrected $\mathrm{p}$ value).

Beside the positional candidate genes, we also looked in more detail at established candidate genes in the region. In the AIRE gene (21q22.3), we analysed two of almost 30 known mutations-R257X in exon 6 and the 13 base pair (bp) deletion in exon 8-which prevail in European populations. $^{2021}$ These two mutations were screened in 96 TID patients, but no carriers were identified. Fine mapping narrowed the linked region proximal to the AIRE gene, also suggesting no TID association of this gene. By proteome analysis (that is, two dimensional gel electrophoresis in IL- $1 \beta$ exposed, diabetes-prone, Bio Breeding (BB-DP) rat islets of Langerhans in vitro), we showed that the protein carbonyl 


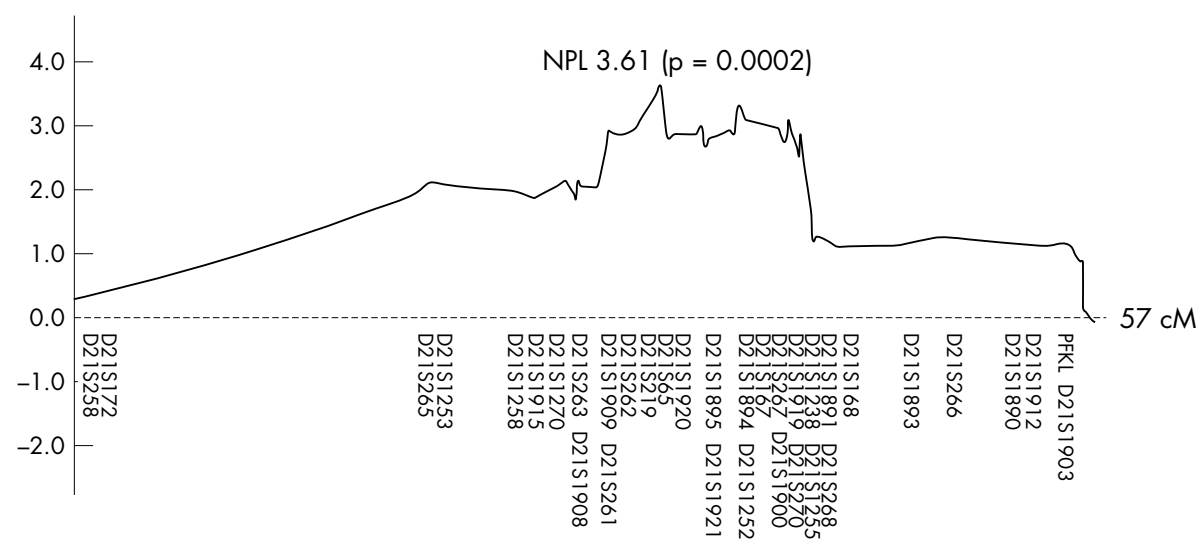

Figure 1 Multipoint non-parametric (NPL) score analysis. Peak maximum NPL score and corresponding p values, as well as approximate position of markers, are indicated.

reductase 1 (CBRI) encoded by the CBRl gene (21q22.12) was downregulated fivefold by IL- $1 \beta$ stimulation. ${ }^{10}$ As IL- $1 \beta$ is believed to be the most important cytokine in the destruction of the $\beta$ cells, ${ }^{11}$ this finding may suggest a role for CBRl in TID, and makes the CBRI gene a functional candidate gene as well. Seven SNPs in coding regions of this gene-as well as two non-coding SNP-have been analysed (table 2); however, none of them demonstrated an association to TID in the complete material.

Recent reports have described regulatory polymorphisms in RUNX1 binding sites in three other autoimmune diseases. ${ }^{14-16}$

\begin{tabular}{|c|c|c|}
\hline Marker & NPL & p Value \\
\hline D21S258 & 0.28 & 0.39 \\
\hline D21S172 & 0.32 & 0.38 \\
\hline D21S265 & 1.98 & 0.02 \\
\hline$D 21 S 1253$ & 2.1 & 0.02 \\
\hline D21S1258 & 1.98 & 0.02 \\
\hline D21S1915 & 1.87 & 0.03 \\
\hline D21S1270 & 2.13 & 0.02 \\
\hline$D 21 S 263$ & 1.87 & 0.03 \\
\hline D21S1908 & 2.06 & 0.02 \\
\hline D21S1909 & 2.05 & 0.02 \\
\hline D21S261 & 2.92 & 0.002 \\
\hline D21S262 & 2.87 & 0.002 \\
\hline D21S219 & 2.96 & 0.002 \\
\hline D21S1920 & 3.61 & 0.0002 \\
\hline$D 21 S 65$ & 2.86 & 0.002 \\
\hline D21S1895 & 2.85 & 0.002 \\
\hline D21S1921 & 2.78 & 0.003 \\
\hline D21S1894 & 2.99 & 0.001 \\
\hline D21S1252 & 3.12 & 0.0009 \\
\hline$D 21 S 167$ & 2.92 & 0.0009 \\
\hline$D 21 S 267$ & 3.05 & 0.001 \\
\hline D21S1900 & 2.55 & 0.005 \\
\hline D21S1919 & 2.68 & 0.004 \\
\hline D21S1255 & 2.6 & 0.005 \\
\hline D21S270 & 2.84 & 0.002 \\
\hline D21S1238 & 1.64 & 0.05 \\
\hline D21S1891 & 1.48 & 0.07 \\
\hline$D 215268$ & 1.27 & 0.1 \\
\hline$D 215168$ & 1.1 & 0.14 \\
\hline D21S1893 & 1.11 & 0.13 \\
\hline$D 21 S 266$ & 1.24 & 0.11 \\
\hline D21S1890 & 1.06 & 0.15 \\
\hline D21S1912 & 0.82 & 0.21 \\
\hline PFKL & 0.13 & 0.45 \\
\hline D21S1903 & -0.08 & 0.53 \\
\hline
\end{tabular}

NPL scores and corresponding $p$ values are shown. Markers conferring the 1 LOD drop support interval are in bold. NPL, non-parametric linkage.
Four cSNPs in RUNX1 (21q22.3) were analysed, as well as the intron $6 \mathrm{SNP}$, the $\mathrm{C}$ allele of which is reported to be associated with rheumatoid arthritis, ${ }^{14}$ but no TID association could be shown in the present study (table 2 ). For the intron 6 SNP (rs2268277), we observed 157 transmissions of the $\mathrm{C}$ allele $v 174$ transmissions of the $\mathrm{G}$ allele to affected offspring in the Sib-TDT test of the 253 TID families. As the rheumatoid arthritis study was a case-control design, we also compared allele frequencies of 242 independent TID patients with the allele frequencies among rheumatoid patients and controls $^{14}$ for the RUNXI intron 6 SNP. The TID allele frequencies resembled the control population and not the distribution in the rheumatoid patients (data not shown).

In addition to testing for association in the complete material, we also carried out stratifications and analysis of subsets of data. Linkage has been demonstrated in the sibling pair families exclusively, and we hypothesised that the likelihood of detecting a susceptibility gene might be greater in families with several affected individuals than in simplex families. We therefore divided our sample into two subgroups, one containing the 155 sibling pair families and one containing the 98 simplex families. All genotyped SNPs were tested for association to TID separately in the two groups. One SNP (rs2835655 in the TTC3 gene), which showed borderline T1D association in the complete material $(\mathrm{p}=0.057)$, was found to be significantly associated to TID in the sibling pair family subgroup (76 v 103 transmissions, $\mathrm{p}=0.04$ ), whereas there was equal transmission (43 $v 47$ transmissions) in the simplex families.

In linkage analyses sibling pair families are exclusively informative and therefore have to be used. As it is likely that only a subset of the families will be responsible for the observed linkage signal, we divided the sibling pair families into two groups according to their linkage signal at the position corresponding to the peak NPL score of 3.61. All genotyped SNPs were then tested for TID association, separately in the subgroup of families with sharing patterns consistent with linkage. For three SNPs, TID association in the "linked" subgroup was demonstrated: for rs762178 in the OLIG2 (oligodendrocyte lineage transcription factor 2) gene, $29 v 11$ transmissions to affected individuals $(\mathrm{p}=0.01)$ were observed, whereas $6 v 6$ transmissions to unaffected offspring were found; for rs 1805127 in the KCNE1 (potassium channel, voltage gated, ISK related subfamily, member 1) gene, $19 v 39$ transmissions to affected offspring $(\mathrm{p}=0.01)$ and $7 \vee 9$ transmissions to unaffected offspring were observed; and finally for rs 20572 in the $C B R 1$ gene, $23 v 7$ transmissions to affected offspring $(\mathrm{p}=0.047)$ and only $2 \vee 2$ transmissions to unaffected offspring were found. For none of these three 
Table 2 Evaluation of 82 single nucleotide polymorphisms in positional candidate genes

\begin{tabular}{|c|c|c|c|c|c|}
\hline & Bases & Amino acid & Material & Result & Gene \\
\hline rs686364 & $\mathrm{T} / \mathrm{C}$ & Ser/Pro & 253 families tested & No association & CLDN8 (21q22.11) \\
\hline rs685967 & $\mathrm{A} / \mathrm{G}$ & Thr/Ala & 253 families tested & No association & CLDN8 (21q22.11) \\
\hline rs 1557294 & $\mathrm{~A} / \mathrm{G}$ & Thr/Ala & 96 TID screened & Not detected & CLDN8 (21q22.11) \\
\hline rs762194 & $\mathrm{T} / \mathrm{C}$ & Gly/Gly & 253 families tested & No association & TIAM1 (21q22.1) \\
\hline rs2070417 & $\mathrm{G} / \mathrm{T}$ & Gly/Val & 253 families tested & No association & TIAM1 (2lq22.1) \\
\hline rs2070418 & $\mathrm{G} / \mathrm{A}$ & Gly/Arg & 253 families tested & No association & TIAMI (2lq22.1) \\
\hline rs 1804450 & $\mathrm{C} / \mathrm{T}$ & $\mathrm{Thr} / \mathrm{lle}$ & 96 TID screened & Not detected & SOD1 (21q22.1) \\
\hline rs 1804449 & $\mathrm{C} / \mathrm{T}$ & Asn/Asn & 96 TID screened & Not detected & SODI (2lq22.1) \\
\hline rs 1804447 & $\mathrm{G} / \mathrm{A}$ & 3'UTR & 96 TID screened & Not detected & SOD1 (2lq22.1) \\
\hline rs 15012 & $\mathrm{~A} / \mathrm{G}$ & 3'UTR & 96 TID screened & Not detected & SODI (2lq22.1) \\
\hline rs 1804448 & $\mathrm{~A} / \mathrm{C}$ & 3'UTR & 96 TID screened & Minor allele frequency $<3 \%$ & SOD1 (2lq22.1) \\
\hline rs 1050089 & $\mathrm{~A} / \mathrm{C}$ & 3'UTR & 96 TID screened & Minor allele frequency $<3 \%$ & SODI (2lq22.1) \\
\hline rs2070371 & $\mathrm{T} / \mathrm{C}$ & Leu/Leu & 253 families tested & No association & HUNK (2lq22) \\
\hline rs6517105 & $\mathrm{A} / \mathrm{G}$ & $\mathrm{His} / \mathrm{Arg}$ & 253 families tested & No association & TCP10 (21q22.11) \\
\hline rs2017816 & $\mathrm{A} / \mathrm{G}$ & Lys/Lys & 253 families tested & No association & TCP10 (21q22.11) \\
\hline rs762178 & $\mathrm{A} / \mathrm{G}$ & Ser/Ser & 253 families tested & No association & OLIG2 (2lq) \\
\hline rs 1058857 & $\mathrm{C} / \mathrm{T}$ & Ser/Ser & 96 TID screened & Not detected & ILIORB (2lq22.1) \\
\hline rs2834167 & $\mathrm{A} / \mathrm{G}$ & Lys/Glu & 253 families tested & No association & IL1ORB (21q22.1) \\
\hline rs 1058859 & $\mathrm{C} / \mathrm{A}$ & Ala/Asp & 96 TID screened & Minor allele frequency $<3 \%$ & IL1ORB (21q22.1) \\
\hline rs 1058861 & $\mathrm{G} / \mathrm{T}$ & Ala/Ser & 96 TID screened & Minor allele frequency $<3 \%$ & IL1ORB (21q22.1) \\
\hline rs 2257167 & $\mathrm{G} / \mathrm{C}$ & $\mathrm{Val} / \mathrm{Leu}$ & 253 families tested & No association & IFNAR1 (21q22.1) \\
\hline rs4986958 & $C / G$ & $\mathrm{Thr} / \mathrm{Arg}$ & 96 T1D screened & Not detected & IFNGR2 (21q22.1-q22.2) \\
\hline rs 1064579 & $T / G$ & $\mathrm{Val} / \mathrm{Gly}$ & 96 TID screened & Minor allele frequency $<3 \%$ & IFNGR2 (21q22.1-q22.2) \\
\hline rs 1802585 & C/A & Asp/Glu & 96 TID screened & Not detected & IFNGR2 (2lq22.1-q22.2) \\
\hline rs2898199 & $\mathrm{A} / \mathrm{T}$ & Glu/Asp & 96 TID screened & Not detected & GART (2lq22.1) \\
\hline rs8971 & $\mathrm{A} / \mathrm{G}$ & Asp/Gly & 253 families tested & No association & GART (2lq22.1) \\
\hline rs 1804387 & $\mathrm{C} / \mathrm{T}$ & Leu/Phe & 96 TID screened & Not detected & GART (21q22.1) \\
\hline rs2409496 & $\mathrm{G} / \mathrm{C}$ & Glu/Gln & Not typed & & GART (2lq22.1) \\
\hline rs7280001 & $\mathrm{C} / \mathrm{T}$ & $\mathrm{His} / \mathrm{His}$ & 96 TID screened & Not detected & SON (21q22.1-22.2) \\
\hline rs7276682 & $\mathrm{A} / \mathrm{C}$ & Ser/Ser & 96 TID screened & Minor allele frequency $<3 \%$ & $\operatorname{SON}(21 q 22.1-22.2)$ \\
\hline rs 1131912 & $\mathrm{C} / \mathrm{T}$ & Pro/Leu & 96 TID screened & Not detected & SON (21q22.1-22.2) \\
\hline rs 1051810 & $\mathrm{~T} / \mathrm{A}$ & Asp/Glu & Not typed & & SON (21q22.1-22.2) \\
\hline rs 1051811 & $\mathrm{~T} / \mathrm{A}$ & $\mathrm{Val} / \mathrm{Glu}$ & Not typed & & SON (21q22.1-22.2) \\
\hline rs7276194 & $\mathrm{T} / \mathrm{C}$ & $\mathrm{Val} / \mathrm{Val}$ & 96 TID screened & Not detected & ITSNI (21q22.1-q22.2) \\
\hline rs2284567 & $\mathrm{C} / \mathrm{T}$ & Ala/Ala & 253 families tested & No association & ITSN1 (21q22.1-q22.2) \\
\hline rs2073370 & $\mathrm{T} / \mathrm{C}$ & Arg/Arg & 253 families tested & No association & ITSN1 (21q22.1-q22.2) \\
\hline rs2834286 & $\mathrm{C} / \mathrm{T}$ & $\mathrm{His} / \mathrm{His}$ & Not typed & & ITSN1 (21q22.1-q22.2) \\
\hline rs 2834296 & $\mathrm{~A} / \mathrm{G}$ & Asn/Asn & 253 families tested & No association & ATP50 (21q22.1-q22.2) \\
\hline rs8129891 & $A / G$ & $\mathrm{Thr} / \mathrm{Ala}$ & 96 TID screened & Not detected & MRPS6 (21q21.3-q22.1) \\
\hline rs4817617 & C/A & Gln/Lys & 96 TID screened & Not detected & MRPS6 (21q21.3-q22.1) \\
\hline rs2234916 & $\mathrm{A} / \mathrm{G}$ & Thr/Ala & 96 TID screened & Minor allele frequency $<3 \%$ & KCNE2 (21q22.1) \\
\hline rs 1805128 & $\mathrm{~A} / \mathrm{G}$ & Asn/Asp & 96 TID screened & Not detected & $\operatorname{KCNE} 1(21 q 22.1-q 22.2)$ \\
\hline rs 1805127 & $\mathrm{~A} / \mathrm{G}$ & Ser/Gly & 253 families tested & No association & KCNE1(21q22.1-q22.2) \\
\hline rs 4252580 & $\mathrm{G} / \mathrm{A}$ & Pro/Pro & 253 families tested & No association & DSCR1 (21q22.1-q22.2) \\
\hline rs7280973 & $\mathrm{A} / \mathrm{G}$ & $\mathrm{Gln} / \mathrm{Gln}$ & 96 TID screened & Not detected & CLIC6 (21q22.12) \\
\hline rs6517254 & $\mathrm{C} / \mathrm{T}$ & Phe/Phe & 253 families tested & No association & CLIC6 (21q22.12) \\
\hline rs3171439 & $\mathrm{A} / \mathrm{G}$ & Asp/Gly & 96 TID screened & Not detected & CLIC6 (2lq22.12) \\
\hline rs 1055309 & $\mathrm{~A} / \mathrm{C}$ & Arg/Ser & 96 TID screened & Not detected & RUNX1 (21q22.3) \\
\hline rs 1055308 & $\mathrm{~A} / \mathrm{C}$ & Arg/Ser & 96 TID screened & Not detected & RUNX1 (2lq22.3) \\
\hline rs 1055307 & $C / G$ & Gly/Gly & 253 families tested & No association & RUNX1 (2lq22.3) \\
\hline rs 1055306 & $\mathrm{C} / \mathrm{T}$ & Gly/Gly & 253 families tested & No association & RUNXI (2lq22.3) \\
\hline rs2268277 & $C / G$ & Intron 6 & 253 families tested & No association & RUNX1 (21q22.3) \\
\hline rs 25678 & $C / G$ & Leu/Leu & 253 families tested & No association & CBR1 (21q22.12) \\
\hline rs 1143663 & $G / A$ & cDNA/UTR & 96 TID screened & Not detected & $C B R 1$ (21q22.12) \\
\hline rs 1051543 & $\mathrm{G} / \mathrm{T}$ & $\mathrm{Val} / \mathrm{Val}$ & 96 TID screened & Minor allele frequency $<3 \%$ & CBR1 (21q22.12) \\
\hline rs2230191 & $\mathrm{G} / \mathrm{A}$ & Thr/Thr & 96 TID screened & Not detected & CBRI (2lq22.12) \\
\hline rs20572 & $\mathrm{C} / \mathrm{T}$ & Ala/Ala & 253 families tested & No association & CBRI (2lq22.12) \\
\hline rs2230192 & $\mathrm{G} / \mathrm{A}$ & $\mathrm{Val} / \mathrm{Val}$ & 96 TID screened & Minor allele frequency $<3 \%$ & CBR1 (21q22.12) \\
\hline rs 1803321 & $\mathrm{~A} / \mathrm{G}$ & 3'UTR & 96 TID screened & Not detected & CBRI (21q22.12) \\
\hline rs5031013 & $\mathrm{A} / \mathrm{C}$ & Leu/Leu & 96 TID screened & Minor allele frequency $<3 \%$ & CBRI (2lq22.12) \\
\hline rs6413462 & $\mathrm{A} / \mathrm{G}$ & lle/Val & 96 TID screened & Not detected & CBRI (2lq22.12) \\
\hline rs2835284 & $\mathrm{A} / \mathrm{G}$ & Gln/Gln & 96 TID screened & Not detected & CBR3 (21q22.2) \\
\hline rs881711 & $\mathrm{C} / \mathrm{T}$ & Asn/Asn & 253 families tested & No association & CBR3 (21q22.2) \\
\hline rs 2835285 & $\mathrm{~A} / \mathrm{G}$ & $\mathrm{Val} / \mathrm{lle}$ & 96 TID screened & Not detected & CBR3 (21q22.2) \\
\hline rs881712 & $\mathrm{C} / \mathrm{T}$ & $\mathrm{Val} / \mathrm{Val}$ & 253 families tested & No association & CBR3 (21q22.2) \\
\hline rs 1056892 & $\mathrm{G} / \mathrm{A}$ & $\mathrm{Val} / \mathrm{Met}$ & 253 families tested & No association & CBR3 (21q22.2) \\
\hline rs2236433 & $\mathrm{A} / \mathrm{T}$ & $\mathrm{lle} / \mathrm{Ile}$ & Not typed & & KIAA0136 (21q22.13) \\
\hline rs219779 & $\mathrm{G} / \mathrm{A}$ & Arg/Arg & 96 TID screened & Minor allele frequency $<3 \%$ & CLDN14 (2lq22.3) \\
\hline rs2073416 & $\mathrm{A} / \mathrm{G}$ & Ser/Ser & 253 families tested & No association & SIM2 (21q22.2) \\
\hline rs2073601 & $\mathrm{A} / \mathrm{C}$ & Met/Leu & 253 families tested & No association & SIM2 (2lq22.2) \\
\hline rs2845804 & $\mathrm{T} / \mathrm{G}$ & Intron & 253 families tested & No association & HLCS (21q22.13) \\
\hline rs219780 & $\mathrm{T} / \mathrm{C}$ & $\mathrm{Thr} / \mathrm{Thr}$ & Not typed & & CLDN14 (21q22.3) \\
\hline rs 1065759 & $\mathrm{C} / \mathrm{T}$ & Asn/Asn & 96 TID screened & Not detected & HLCS (21q22.13) \\
\hline rs 1065758 & $\mathrm{C} / \mathrm{T}$ & Ser/Ser & 253 families tested & No association & HLCS (21q22.13) \\
\hline rs2230182 & $\mathrm{C} / \mathrm{T}$ & Pro/Pro & 253 families tested & No association & HLCS (21q22.13) \\
\hline rs2276231 & $\mathrm{A} / \mathrm{C}$ & Arg/Ser & 96 TID screened & Minor allele frequency $<3 \%$ & DSCR5 (2lq22.13) \\
\hline rs2154538 & $\mathrm{A} / \mathrm{G}$ & $\mathrm{Val} / \mathrm{Val}$ & 253 families tested & No association & TTC3 (2lq22.13) \\
\hline rs2835632 & $\mathrm{A} / \mathrm{G}$ & Lys/Lys & 96 TID screened & Not detected & TTC3 (2lq22.13) \\
\hline rs 1053853 & $G / A$ & Lys/Lys & 96 TID screened & Not detected & TTC3 (2lq22.13) \\
\hline
\end{tabular}




\begin{tabular}{|c|c|c|c|c|c|}
\hline & Bases & Amino acid & Material & Result & Gene \\
\hline rs 1053856 & $G / A$ & Lys/Lys & 96 TID screened & Not detected & TTC3 (21q22.13) \\
\hline rs2835655 & G/A & Lys/Lys & 253 families tested & No association & TTC3 (21q22.13) \\
\hline rs 1053966 & $\mathrm{G} / \mathrm{C}$ & His/Asp & 96 TID screened & Minor allele frequency $<3 \%$ & TTC3 (21q22.13) \\
\hline
\end{tabular}

SNPs could association in the "unlinked" subgroup of families be detected.

In order to evaluate the degree of linkage disequilibrium in the region, we assessed the pairwise LD indices between all microsatellite markers and coding SNPs, with a minor allele frequency of $>3 \%$, located in the "one LOD drop" support interval of $6.3 \mathrm{Mb}$ (44 markers in all). Parental haplotypes were estimated by maximum likelihood estimates in GeneHunter version 1.2 and $\mathrm{D}^{\prime}$ values calculated in HaploXT (http://archimedes.well.ox.ac.uk/pise/haploxt-simple. html); the resulting pairwise $\mathrm{D}^{\prime}$ values are shown in table 3 (only marker sets with $\mathrm{D}^{\prime}$ values above 0.5 are given). Only a few small blocks with a threshold of $\mathrm{D}^{\prime}>0.5$ were identified, including a block containing five consecutive markers (D21S267-D21S1900-rs2154538-rs2835655-D21S1919) and a block with three markers (rs881711-rs881712-rs1056892).

\section{Haplotype testing}

For all 35 microsatellite markers, we constructed haplotypes of three, four, and five adjacent microsatellite markers. The three and four marker haplotypes with a significantly distorted transmission (examined by TDT) to affected offspring are listed in tables 4 and 5. Only haplotypes transmitted or non-transmitted more than five times are listed. Haplotypes of five adjacent markers showed too few transmissions to be informative, as a maximum of only four transmissions for any of these five marker combinations was identified. Seven and 28 haplotypes of the four and three marker haplotypes, respectively, showed association to TID. The location of these haplotypes, corresponding to the "one LOD drop" interval, is indicated by marker names in bold.

\section{DISCUSSION}

TID is considered to be a complex genetic trait, with multiple genetic loci as well as environmental factors contributing to susceptibility. The genetics of TID were initially studied by evaluating candidate genes for association to the disease, in either case-control or family based studies. The only consistent genes and regions showing significant TID association have been the HLA region (6p21.3), the insulin gene region (1lpl5), and more recently CTLA4 (2q33). ${ }^{22}$ Several genome-wide linkage analyses in TlD have been undertaken, aiming at identifying the genetic determinants. Five complete genome scans, ${ }^{32-26}$ a combined analysis of British and American genome scan data, ${ }^{27}$ and some partial scans $^{28-32}$ have been done. In all, more than 20 genomic regions showing varying degrees of linkage to TID have been identified. The aetiological mutation has not been determined for any of the identified TID loci. Even in the HLA region several genes seem to be involved. ${ }^{2}$ Most of the other putative loci comprise regions of up to $40 \mathrm{cM}$ containing several genes (reviewed by Pociot and $\mathrm{McDermott}^{2}$ ). Mapping these genes is a major challenge, but it is important that identifications of linked regions in genome scans are followed by fine mapping in the same populations. Recently, the first identifications of disease-causing genes in complex diseases (Crohn's disease, asthma, and myocardial infarction) based on linkage analysis have been published, showing the feasibility of this approach. ${ }^{33-36}$

Based on the linkage results on chromosome 21 in the Scandinavian genome scan, ${ }^{3}$ our current study provides an opportunity to identify genes of importance for TID disposition on this chromosome in ethnically homogeneous populations such as the Danish and Scandinavian. Chromosome 21 is also interesting because an increased prevalence of TID in Down's syndrome has been reported ${ }^{37-39}$ and an earlier peak age at onset is suggested as well. ${ }^{40}$ These observations, or some of them, could be a reflection of trisomy $21,{ }^{41}$ supporting the possible existence of TID associated genes on this chromosome, and are probably also important in TID in the general population. Furthermore, the existence of several functional candidate genes in the region makes it interesting.

The strategy used for the current project was to narrow the linked region, initially by linkage analysis including an increased number of microsatellites covering the region of

Table 3 Pairwise linkage disequilibrium values

\begin{tabular}{|c|c|c|c|c|c|}
\hline \multicolumn{3}{|c|}{$\begin{array}{l}\text { Pairwise LD with consecutive markers, combinations } \\
\text { with } D^{\prime}>0.5\end{array}$} & \multicolumn{3}{|c|}{$\begin{array}{l}\text { Additional (non-consecutive) pairwise combinations } \\
\text { with } D^{\prime}>0.5\end{array}$} \\
\hline Marker 1 & Marker 2 & $D^{\prime}$ value & Marker 1 & Marker 2 & $D^{\prime}$ value \\
\hline rs762194 & rs2070417 & 0.359 & rs2070418 & rs4252580 & 0.689 \\
\hline rs2070417 & rs 2070418 & 0.964 & rs 2257167 & rs 1055307 & 0.68 \\
\hline rs6517105 & rs2017816 & 0.527 & rs 2257167 & rs 1055306 & 0.601 \\
\hline rs8971 & D21S219 & 0.581 & rs8971 & rs2284567 & 0.679 \\
\hline rs2073370 & rs 2834296 & 0.923 & rs 1055306 & rs2230182 & 0.796 \\
\hline rs 4252580 & D21S65 & 0.577 & rs881711 & rs 1056892 & 0.694 \\
\hline rs1055307 & rs 1055306 & 0.878 & D21S267 & rs2154538 & 0.676 \\
\hline rs 25678 & rs 20572 & 0.89 & $D 21 S 267$ & rs 2835655 & 0.755 \\
\hline rs881711 & rs881712 & 0.849 & D21S1900 & rs2835655 & 0.59 \\
\hline rs881712 & rs 1056892 & 0.661 & D21S1900 & D21S1919 & 0.514 \\
\hline rs2073416 & rs2073601 & 0.816 & rs 2154538 & D21S1919 & 0.656 \\
\hline rs2154538 & rs 2835655 & 0.9 & & & \\
\hline rs 2835655 & D21S1919 & 0.598 & & & \\
\hline
\end{tabular}

Only combinations of any two markers with $D^{\prime}$ values above 0.5 are shown.

LD, linkage disequilibrium. 
Table 4 Three-marker haplotypes showing significant association to type 1 diabetes

Haplotype

\begin{tabular}{|c|c|c|c|c|c|}
\hline 1 & 2 & 3 & Transmissions & Non-transmissions & p Value \\
\hline D21S1258*10 & D21S1915*4 & $D 2151270 * 9$ & 0 & 10 & 0.002 \\
\hline$D 21 S 1258 * 10$ & $D 21 S 1915^{*} 4$ & $D 2151270 * 16$ & 7 & 0 & 0.008 \\
\hline$D 21 S 1915 * 4$ & $D 21 S 1270 * 8$ & $D 21 S 263 * 3$ & 5 & 0 & 0.025 \\
\hline$D 21 S 1915^{*} 4$ & $D 2151270 * 14$ & $D 21 S 263 * 3$ & 10 & 4 & 0.11 \\
\hline D21S1915*4 & D21S1270*17 & $D 21 S 263^{*} 6$ & 0 & 5 & 0.025 \\
\hline$D 21 S 1270 * 19$ & D21S263*7 & D21S1908*5 & 1 & 8 & 0.02 \\
\hline$D 21 S 263 * 3$ & D21S1908*4 & D21S1909*16 & 18 & 8 & 0.049 \\
\hline D21S1908*7 & D21S1909*12 & $D 215261 * 3$ & 0 & 6 & 0.014 \\
\hline D21S1909*12 & $D 215261 * 3$ & $D 21 S 262 * 9$ & 0 & 5 & 0.025 \\
\hline$D 21 S 261 * 2$ & $D 21 S 262 * 9$ & $D 21 S 219 * 4$ & 13 & 3 & 0.012 \\
\hline$D 21 S 261 * 5$ & $D 21 S 262 * 9$ & $D 21 S 219 * 6$ & 0 & 5 & 0.025 \\
\hline$D 21 S 262 * 8$ & D21S219*6 & $D 21 S 65 * 5$ & 0 & 5 & 0.025 \\
\hline$D 21 S 262 * 9$ & $D 21 S 219 * 4$ & $D 21565 * 6$ & 9 & 2 & 0.035 \\
\hline D21S262*9 & $D 21 S 219 * 4$ & $D 21565 * 9$ & 13 & 4 & 0.029 \\
\hline D21S262*10 & $D 21 S 219 * 4$ & $D 21565 * 9$ & 1 & 7 & 0.034 \\
\hline D21S262*10 & $D 21 S 219 * 6$ & D21S65*9 & 1 & 8 & 0.02 \\
\hline D21S219*5 & $D 21 S 65 * 4$ & D21S1920*8 & 8 & 0 & 0.005 \\
\hline$D 21 S 219 * 6$ & $D 21 S 65 \star 8$ & D21S1920*7 & 5 & 0 & 0.025 \\
\hline D21S65*9 & D21S1920*7 & D21S1895*9 & 5 & 0 & 0.025 \\
\hline$D 21 S 1920 * 4$ & D21S1895*3 & D21S1921*8 & 0 & 5 & 0.025 \\
\hline$D 21 S 1921 * 5$ & D21S1894*4 & D21S1252*5 & 2 & 9 & 0.035 \\
\hline$D 21 S 1894 * 4$ & D21S1252*10 & $D 215167^{*} 13$ & 3 & 11 & 0.033 \\
\hline D21S1894*5 & D21S1252*5 & $D 215167^{*} 13$ & 11 & 2 & 0.013 \\
\hline$D 21 S 267 * 4$ & $D 2151900 * 8$ & D21S1919*16 & 1 & 8 & 0.02 \\
\hline$D 21 S 267 * 5$ & $D 2151900 * 8$ & D21S1919*10 & 5 & 0 & 0.025 \\
\hline$D 21 S 267^{* 5}$ & $D 2151900 * 8$ & D21S1919*14 & 0 & 6 & 0.014 \\
\hline D21S1900*8 & D21S1919*2 & $D 21 S 270 * 8$ & 5 & 0 & 0.025 \\
\hline D21S1919*2 & D21S270*8 & D21S1238*1 & 5 & 0 & 0.025 \\
\hline
\end{tabular}

Transmissions $v$ non-transmissions of the haplotype in TDT test and the respective $p$ values are given. Markers corresponding to the "one LOD drop" support interval are shown in bold.

interest in a multipoint NPL analysis. This strategy has been applicable since the chromosome was fully sequenced, though there is still some uncertainty about the exact map order of some of the markers. For the current study we initially used the Marshfield map (http://research. marshfieldclinic.org) for selection of microsatellite markers, but after advances in the completion of the human genome sequence, we used marker order and inter-marker distances based on the physical map of chromosome 21 (NCBI, National Center for Biotechnology Information; http:// www.ncbi.nlm.nih.gov) for further analyses. A recent study has shown the importance and impact of correct marker order for linkage analyses. ${ }^{42}$

By multipoint NPL analysis, a maximum NPL score of 3.61 was obtained at marker D21S1920, compared with a maximum LOD score of 2.33 (NPL score 2.64) in this population in the original study. ${ }^{3}$ Based on a recent study of asthma susceptibility, it has been shown that the one-LOD decrease in the support interval of the linkage peak is likely to contain the susceptibility locus if the region has been saturated with markers. ${ }^{35}$ In the present study the information content of this region was $95-100 \%$. We therefore identified the corresponding support interval using NPL statistics (referred to as the "one LOD drop" interval) and found that it covered approximately $6.3 \mathrm{Mb}$, which was further studied by LD mapping with gene based SNPs.

The disease related LD was also assessed by a haplotype based association study. Of the four-marker haplotypes, seven were found to be significantly associated to TID, six of which are located in the "one LOD drop" interval. Regarding three-marker haplotypes, 28 were shown to be associated to TID, of which 21 were also located in the "one LOD drop" interval. That several haplotypes showed distorted transmission to diabetic offspring supports the existence of TID susceptibility genes in this region.

We identified 32 candidate genes in this narrowed region. Several strategies can be chosen from here, ideally applying resequencing of all candidate genes in order to identify all mutations. In view of the still quite significant number, we chose to examine the genes by identifying SNPs in coding regions (cSNPs) of the genes, and initially to screen the identified 74 cSNPs in a panel of 96 diabetic subjects. SNPs with a minor allele frequency above 3\% were further examined. These SNPs were genotyped in the complete

Table 5 Four-marker haplotypes showing significant association to type 1 diabetes

\begin{tabular}{|c|c|c|c|c|c|c|}
\hline \multicolumn{4}{|l|}{ Haplotype } & \multirow[b]{2}{*}{ Transmissions } & \multirow[b]{2}{*}{ Non-transmissions } & \multirow[b]{2}{*}{ p Value } \\
\hline 1 & 2 & 3 & 4 & & & \\
\hline D21S1915*4 & D21S1270*19 & D21S263*7 & D21S1908*5 & 1 & 8 & 0.02 \\
\hline D21S262*10 & D21S219*4 & $D 21 S 65 * 9$ & D21S1920*7 & 0 & 7 & 0.008 \\
\hline D21S1921*5 & D21S1894*4 & D21S1252*5 & $D 21 S 167^{*} 13$ & 0 & 5 & 0.025 \\
\hline D21S1894*5 & D21S1252*5 & $D 21 S 167^{*} 13$ & $D 21 S 267 * 4$ & 5 & 0 & 0.025 \\
\hline$D 21 S 267^{*} 11$ & $D 21 S 1900 * 8$ & D21S1919*2 & $D 21 S 270 * 8$ & 5 & 0 & 0.025 \\
\hline D21S1900*8 & D21S1919*2 & D21S270*8 & $\mathrm{D} 21 S 1238^{\star} 1$ & 5 & 0 & 0.025 \\
\hline D21S1919*2 & D21S270*7 & D21S1238*1 & D21S1255*7 & 5 & 0 & 0.025 \\
\hline
\end{tabular}

Transmissions $v$ non-transmissions of the haplotype in TDT test and the respective p values are given. Markers corresponding to the "one LOD drop" support interval are shown in bold. 
Danish TID family material and examined for TID association. However, none of the SNPs showed association to TID, whereas one SNP in the TTC3 gene did show distorted transmission to unaffected offspring, which might indicate a possible protective effect. The TTC3 gene is expressed in most human tissues, including pancreas. It has been speculated that overexpression of this gene might be involved in some of the morphological anomalies observed in Down's syndrome. ${ }^{43}$ We also undertook stratification of SNP data by dividing genotyping data in subgroups, according to simplex or sibling pair family status, and according to families carrying the linkage signal in the region and families not consistent with linkage, respectively. This approach is based on a theory predicting that genetically loaded individuals of families presumably provide a stronger signal and might facilitate identification of disease susceptibility variants. ${ }^{44}$ This strategy of selecting families that show evidence for linkage to a region for further studies has been suggested and implemented previously. ${ }^{35}{ }^{45}$ Interestingly, we showed significant TID association of a TTC3 SNP rs2835655 in the sibling pair family subgroup, and additionally two other SNPs-rs762178 (OLIG2) and rs1805127 (KCNE1) - showed association in the subgroup of families responsible for the observed TID linkage of the region. The degree of linkage disequilibrium in the linked region of $6.3 \mathrm{Mb}$ was evaluated by pairwise LD measurements; however, we were only able to identify two blocks extending more than two markers with $\mathrm{D}^{\prime}$ values $>0.5$. Thus there do not appear to be large blocks with strong LD in this region, in agreement with previous studies on chromosome 21,4647 though one block containing five markers was demonstrated, spanning approximately $100 \mathrm{~kb}$.

A few established candidate genes for autoimmune diseases are mapped to the region demonstrating linkage in the present study. The AIRE gene, originally considered a candidate gene of the linked region, was screened in 96 TID patients for the two most common mutations causing the APECED syndrome in white populations, but no mutation carriers were identified. However, following the current fine mapping, the AIRE gene is no longer localised in the linked region but distal to this, and we did not continue with resequencing and further examinations of the gene. In support of this, others equally have been unable to identify any of these two mutations in TID populations. ${ }^{9218}$ Furthermore, disomic homozygosity at the APECED locus has been proven not to be capable of explaining the increased level of autoimmunity in Down's syndrome. ${ }^{49}$

CBR-1 protein in rat islets is significantly downregulated following cytokine exposure ${ }^{10}$ and is therefore likely to play a role in cytokine mediated $\beta$ cell destruction. Typing seven cSNPs and two SNPs in 3'UTR of the CBRI gene did not show any significant association. However, in the "linked" family subgroup analysis, a significant association to T1D was found for the CBRI cSNP, rs20572 ( $\mathrm{p}=0.047)$.

Alloxan and streptozotocin (STZ) are pancreatic $\beta$ cell selective toxins that have been used to probe the mechanisms underlying oxygen mediated damage to rodent $\beta$ cells. Pretreatment with or concomittant administration of SODl confer protection against alloxan or STZ induced diabetes, ${ }^{50} 51$ and cultured rodent islets can be protected from alloxan or STZ induced impairment. ${ }^{51}{ }^{52}$ Specific activity of pancreatic SODl has been shown to be significantly increased in alloxan resistant (ALR/Lt) compared with alloxan susceptible (ALS/ Lt) mice, ${ }^{12}$ and SODl transgenic mice are protected against oxidative stress. ${ }^{53}{ }^{54}$ In addition to two cSNPs, we also typed four SNPs of the 3'UTR. However, none of these showed association to TID.

Indications that RUNXl might be a common factor in autoimmunity have recently come from reports of disease associated mutations in RUNXI binding sites in three other autoimmune diseases. ${ }^{14-16}$ In addition, association of the regulatory $P D C D 1$ variation originally found with $\mathrm{SLE}^{16}$ has been replicated in TID..$^{55}$ These reports make the RUNXI gene very interesting in TID, substantiated by the location of the linkage peak we report here in exactly this region. RUNXI protein is a DNA binding transcription factor with the context specific capability of activating or repressing gene expression. ${ }^{56}$ We were not able to demonstrate any significant linkage of the known coding SNPs in this gene, nor of the intronic SNP in intron 6 of the RUNXI gene, which is associated to rheumatoid arthritis. ${ }^{14}$ The allele showing association to rheumatoid arthritis in a dominant model was the $\mathrm{C}$ allele, ${ }^{14}$ whereas in a family based study we were not able to show an increased transmission of the $\mathrm{C}$ allele to TID affected offspring. On the other hand, we saw a slightly increased transmission of the $G$ allele to affected offspring, though this was not significant. Allele frequency distribution for this SNP in TID patients does not resemble that of the rheumatoid patients either. However, TID association of borderline significance was observed in the "linked" family subgroup analysis for $\operatorname{rs} 1055307(\mathrm{p}=0.055)$. In addition, preliminary data from our group have shown that the mRNA expression of $A M L 1$ (RUNXI) was significantly downregulated in a rat insulin producing cell line after exposure to IL- 1 using Affymetrix chip analysis (Affymetrix Inc, Santa Clara, California, USA) (Nielsen K, personal communication), suggesting that RUNXI regulated gene expression may also be relevant in TID pathogenesis.

Our data suggest that one or several TID linked genes exists in the region, even though no evidence for association was found for the tested SNPs in the complete material. Despite evidence for linkage in the Danish population, linkage to TID on chromosome 21 has not been reported in other genome scans. However, it cannot be ruled out that it was missed in other studies owing to the inclusion of relatively few markers of this region on chromosome 21 . It is estimated that the information content of this particular region in previous genome scans did not exceed around 0.66. Certainly further genotyping and refinement of the genetic map corresponding to this region on chromosome 21 is important. Our data have so far not been replicated in other populations as our strategy was initially to fine map the linked region in the same populations in which linkage was demonstrated, in order to localise a specific gene and show aetiological or otherwise significant mutations, before replicating the findings in other populations.

LD mapping with SNPs coupled with genome scans is being used increasingly and is considered valuable for fine mapping and genetic association studies. ${ }^{57}{ }^{58}$ Genotyping this number of SNPs is still time consuming and costly, but important in terms of fully characterising and fine mapping this region on chromosome 21 . Identification of a disease associated gene based on linkage analysis has so far never been obtained successfully in TID.

Our study reduced the region linked to TID from more than $20 \mathrm{Mb}$ to $6.3 \mathrm{Mb}$ and increased the NPL score from 2.64 to 3.61. Furthermore, the number of possible susceptibility genes was reduced to 32. Although we were not able to identify a single gene variant responsible for the observed linkage, we demonstrated significant support for several combinations of markers within this region, and some evidence for association to TID of variants of the TTC3, OLIG2, KCNE1, and CBRI genes in conditioned analyses.

As our data strongly suggest the existence of TID linked genes in the region, further characterisation of the candidate genes on chromosome 21 is very important, implying analyses of regulatory and promoter regions, in which variants of potential importance in regulation of gene expression and thereby functional significance are likely to 
be located. The possible significance of non-coding SNPs in disease predisposition have been demonstrated several times (for example, CALP10, CTLA4, and RUNXI). ${ }^{14-162245}$

The identification of genes responsible for disease will lead to a better understanding of the mechanisms underlying the disease process and thereby perhaps in the future be helpful specifically in developing intervention against T1D.

\section{ACKNOWLEDGEMENTS}

We thank Rikke Bonne and Bodil Bosmann Jørgensen for excellent technical assistance and Karin Nielsen for sharing unpublished data. Drs Jesper Johannesen and Ole Peter Kristiansen, the Danish Study Group for Diabetes in Childhood, and the Danish IDDM Epidemiology and Genetics Group are acknowledged for their help in collection of the Danish families. The Foundation of 17-12-1981, the Danish Diabetes Association, the Aase and Ejnar Danielsen Foundation, and the Foundation for Laegevidenskabens Fremme are acknowledged for their support.

\section{Authors' affiliations \\ R Bergholdt, J Nerup, F Pociot, Steno Diabetes Centre, DK-2820 Gentofte, Denmark}

Competing interests: none declared

\section{REFERENCES}

Borch-Johnsen K. The prognosis of insulin-dependent diabetes mellitus. An epidemiological approach. Dan Med Bull 1989;36:336-48.

2 Pociot F, McDermott MF. Genetics of type 1 diabetes mellitus. Genes Immun 2002;3:235-49.

3 Nerup J, Pociot F, European Consortium for IDDM genome studies. A genomewide scan for type 1-diabetes susceptibility in Scandinavian families: identification of new loci with evidence of interactions. Am J Hum Genet 2001;69:1301-13.

4 Pociot $F$, Karlsen AE, Pedersen CB, Aalund M, Nerup J. Novel analytical methods applied to type 1 diabetes genome scan data. Am J Hum Genet 2004;74:647-60.

5 Hattori M, Fujiyama A, Taylor TD, Watanabe H, Yada T, Park HS, Toyoda A, Ishii K, Totoki Y, Choi DK, Soeda E, Ohki M, Takagi T, Sakaki Y, Taudien S, Blechschmidt K, Polley A, Menzel U, Delabar J, Kumpf K, Lehmann R, Patterson D, Reichwald K, Rump A, Schillhabel M, Schudy A, Zimmermann W, Rosenthal A, Kudoh J, Schibuya K, Kawasaki K, Asakawa S, Shintani A, Sasaki T, Nagamine K, Mitsuyama S, Antonarakis SE, Minoshima S Shimizu N, Nordsiek G, Hornischer K, Brant P, Scharfe M, Schon O, Desario A, Reichelt J, Kaver G, Blocker H, Ramser J, Beck A, Klages S, Hennig S, Riesselmann L, Dagand E, Haaf T, Wehrmeyer S, Borzym K, Gardiner K, Nizetic D, Francis F, Lehrach H, Reinhardt R, Yaspo ML. The DNA sequence of human chromosome 21. Nature 2000;405:31 1-19.

6 Perheentupa J. Autoimmune polyendocrinopathy-candidiasis-ectodermal dystrophy (APECED). Horm Metab Res 1996;28:353-6.

7 Biorses P, Halonen M, Palvimo JJ, Kolmer M, Aaltonen J, Ellonen P, Perheentupa J, Ulmanen I, Peltonen L. Mutations in the AIRE gene: Effects on subcellular location and transactivation function of the autoimmune polyendocrinopathy-candidiasis-ectodermal dystrophy protein. Am J Hum Genet 2000;66:378-92.

8 Scott HS, Heino M, Peterson P, Mittaz L, Lalioti MD, Betterle C, Cohen A, Seri M, Lerone M, Romeo G, Collin P, Salo M, Metcalfe R, Weetman A, Papasavvas MP, Rossier C, Nagamine K, Kudoh J, Shimizu N, Krohn KJE, Antonarakis SE. Common mutations in autoimmune polyendocrinopathycandidiasis ectodermal dystrophy patients of different origins. Mol Endocrinol 1998;12:1112-19.

9 Meyer G, Badenhoop K. Autoimmune regulator (AIRE) gene on chromosome 21: Implications for autoimmune polyendocrinopathy-candidiasis- ectodermal dystrophy (APECED) any-more common manifestations of endocrine autoimmunity. J Endocrinol Invest 2002;25:804-11

10 Sparre T, Christensen UB, Larsen PM, Fey SJ, Wrzesinski K, Roepstorff P, Mandrup-Poulsen T, Pociot F, Karlsen AE, Nerup J. IL-1 beta induced protein changes in diabetes prone $B B$ rat islets of Langerhans identified by proteome analysis. Diabetolog 2002;45:1550-61.

11 Nerup J, Mandruppoulsen T, Helqvist S, Andersen HU, Pociot F, Reimers JI, Cuartero BG, Karlsen AE, Bierre U, Lorenzen T. On the pathogenesis of IDDM. Diabetolog 1994;37(suppl 2):S82-9.

12 Mathews CE, Leiter EH. Constitutive differences in antioxidant defense status distinguish alloxan-resistant and alloxan-susceptible mice. Free Radic Biol Med 1999;27:449-55.

13 Mathews CE, Dunn BD, Hannigan MO, Huang CK, Leiter EH. Genetic control of neutrophil superoxide production in diabetes-resistant ALR/Lt mice. Free Radic Biol Med 2002;32:744-51.

14 Tokuhiro S, Yamada R, Chang XT, Suzuki A, Kochi Y, Sawada T, Suzuki M, Nagasaki M, Ohtsuki M, Ono M, Furukawa H, Nagashima M, Yoshino S, Mabuchi A, Sekine A, Saito S, Takahashi A, Tsunoda T, Nakamura Y, Yamamoto K. An intronic SNP in a RUNX1 binding site of SLC22A4, encoding an organic cation transporter, is associated with rheumatoid arthritis. Nature Genet 2003;35:341-8.
15 Helms C, Cao L, Krueger JG, Wiisman EM, Chamian F, Gordon D, Heffernan M, Daw JAW, Robarge J, Ott J, Kwok PY, Menter A, Bowcock AM. A putative RUNX1 binding site variant between SLC9A3R1 and NAT9 is associated with susceptibility to psoriasis. Nature Genet 2003;35:349-56.

16 Prokunina L, Castillejo-Lopez C, Oberg F, Gunnarsson I, Berg L, Magnusson V, Brookes AJ, Tentler D, Kristjansdottir H, Grondal G, Bolstad Al, Svenungsson E, Lundberg I, Sturfelt $G$, Jonssen A, Truedsson L, Lima G, Alcocer-Varela J, Jonsson R, Gyllensten UB, Harley JB, Alarcon-Segovia D, Steinsson K, Alarcon-Riquelme ME. A regulatory polymorphism in PDCDI is associated with susceptibility to systemic lupus erythematosus in humans 2002;32:666-9.

17 Lorenzen T, Pociot F, Stilgren L, Kristiansen OP, Johannesen J, Olsen PB, Walmar A, Larsen A, Albrechtsen NC, Eskildsen PC, Andersen OO, Nerup J. Predictors of IDDM recurrence risk in offspring of Danish IDDM patients. Diabetolog 1998;41:666-73.

18 Kruglyak L, Daly MJ, Reevedaly MP, Lander ES. Parametric and nonparametric linkage analysis - a unified multipoint approach. Am J Hum Genet 1996;58:1347-63.

19 Spielman RS, Ewens WJ. A sibship test for linkage in the presence of association: the sib transmission/disequilibrium test. Am J Hum Genet 1998;62:450-8.

20 Pearce SHS, Cheetham T, Imrie H, Vaidya B, Barnes ND, Bilous RW, Carr D, Meeran K, Shaw NJ, Smith CS, Toft AD, Williams G, Kendall-Taylor P. A common and recurrent 13-bp deletion in the autoimmune regulator gene in British kindreds with autoimmune polyendocrinopathy type 1. Am J Hum Genet 1998;63:1675-84

21 Meyer G, Donner H, Herwig J, Bohles H, Usadel KH, Badenhoop K. Screening for an AIRE-1 mutation in patients with Addison's disease, type 1 diabetes, Graves' disease and Hashimoto's thyroiditis as well as in APECED syndrome. Clin Endocrinol 2001;54:335-8.

22 Ueda H, Howson JMM, Esposito L, Heward J, Snook H, Chamberlain G, Rainbow DB, Hunter KMD, Smith AN, Di-Genova G, Herr MH, Dahlman I, Payne F, Smyth D, Lowe C, Twells RCJ, Howlett S, Healy B, Nutland S Rance HE, Everett V, Smink U, Lam AC, Cordell HJ, Walker NM, Bordin C, Hulme J, Motzo C, Cucca F, Hess JF, Metzker ML, Rogers J, Gregory S, Allahabadia A, Nithiyananthan R, Tuomilehto-Wolf E, Tuomilehto J, Bingley P, Gillespie KM, Undlien DE, Ronningen KS, Guja C, lonescu-Tirgoviste C, Savage DA, Maxwell AP, Carson DJ, Patterson CC, Franklyn JA, Clayton DG, Peterson LB, Wicker LS, Todd JA, Gough SCL. Association of the T-cell regulatory gene CTLA4 with susceptibility to autoimmune disease. Nature 2003;423:506-11.

23 Davies JL, Kawaguchi Y, Bennett ST, Copeman JB, Cordell HJ, Pritchard LE, Reed PW, Gough SCL, Jenkins SC, Palmer SM, Balfour KM, Rowe BR, Farrall M, Barnett AH, Bain SC, Todd JA. A genome-wide search for human type-1 diabetes susceptibility genes. Nature 1994;371:130-6.

24 Hashimoto L, Habita C, Beressi JP, Delepine M, Besse C, Cambon-Thomsen A, Deschamps I, Rotter JI, Djoulah S, James MR. Genetic mapping of a susceptibility locus for insulin-dependent diabetes mellitus on chromosome 11 q. Nature 1994;371:161-4.

25 Concannon P, Gogolin-Ewens KJ, Hinds DA, Wapelhorst B, Morrison VA, Stirling B, Mitra M, Farmer J, Williams SR, Cox NJ, Bell GI, Risch N, Spielman RS. A second-generation screen of the human genome for susceptibility to insulin-dependent diabetes mellitus. Nat Genet 1998; 19:292-6.

26 Mein CA, Esposito L, Dunn MG, Johnson GC, Timms AE, Goy JV, Smith AN, Sebag-Montefiore L, Merriman ME, Wilson AJ, Pritchard LE, Cucca F, Barnett AH, Bain SC, Todd JA. A search for type 1 diabetes susceptibility genes in families from the United Kingdom. Nat Genet 1998;19:297-300.

27 Cox NJ, Wapelhorst B, Morrison VA, Johnson L, Pinchuk L, Spielman RS, Todd JA, Concannon P. Seven regions of the genome show evidence of linkage to type 1 diabetes in a consensus analysis of 767 multiplex families. Am J Hum Genet 2001;69:820-30.

28 Field LL, Tobias R, Magnus T. A locus on chromosome 15q26 (IDDM3) produces susceptibility to insulin-dependent diabetes mellitus. Nat Genet 1994:8:189-94.

29 Rowe RE, Wapelhorst B, Bell GI, Risch N, Spielman RS, Concannon P. Linkage and association between insulin-dependent diabetes mellitus (IDDM) susceptibility and markers near the glucokinase gene on chromosome 7. Nat Genet 1995; 10:240-2.

30 Luo DF, Bui MM, Muir A, Maclaren NK, Thomson G, She JX. Affected-sib-pair mapping of a novel susceptibility gene to insulin-dependent diabetes mellitus (IDDM8) on chromosome 6q25-q27. Am J Hum Genet 1995;57:911-19.

31 Field LL, Tobias R, Thomson G, Plon S. Susceptibility to insulin-dependent diabetes mellitus maps to a locus (IDDM1 1) on human chromosome 14q24.3q31. Genomics 1996;33:1-8.

32 Delepine M, Pociot F, Habita C, Hashimoto L, Froguel P, Rotter J, CambonThomsen A, Deschamps I, Djoulah S, Weissenbach J, Nerup J, Lathrop M, Julier C. Evidence of a non-MHC susceptibility locus in type I diabetes linked to HLA on chromosome 6. Am J Hum Genet 1997;60:174-87.

33 Hugot JP, Chamaillard M, Zouali H, Lesage S, Cezard JP, Belaiche J, Almer S, Tysk C, O'Morain CA, Gassull M, Binder V, Finkel Y, Cortot A, Modigliani R, Laurent-Puig P, Gower-Rousseau C, Macry J, Colombel JF, Sahbatou M, Thomas G. Association of NOD2 leucine-rich repeat variants with susceptibility to Crohn's disease. Nature 2001;411:599-603.

34 Ogura Y, Bonen DK, Inohara N, Nicolae DL, Chen FF, Ramos R, Britton H, Moran T, Karaliuskas R, Duerr RH, Achkar JP, Brant SR, Bayless TM, Kirschner BS, Hanauer SB, Nunez G, Cho JH. A frameshift mutation in NOD2 associated with susceptibility to Crohn's disease. Nature 2001;411:603-6.

35 Van-Eerdewegh P, Little RD, Dupuis J, Del-Mastro RG, Falls K, Simon J, Torrey D, Pandit S, McKenny J, Braunschweiger K, Walsh A, Liu ZY, Hayward B, Folz C, Manning SP, Bawa A, Saracino L, Thackston M, 
Benchekroun $Y$, Capparell N, Wang $M$, Adair R, Feng Y, Dubois J, FitzGerald MG, Huang H, Gibson R, Allen KM, Pedan A, Danzig MR, Umland SP, Egan RW, Cuss FM, Rorke S, Clough JB, Holloway JW, Holgate ST, Keith TP. Association of the ADAM33 gene with asthma and bronchial hyperresponsiveness. Nature 2002;418:426-30.

36 Helgadottir A, Manolescu A, Thorleifsson G, Gretarsdottir S, Jonsdottir H Thorsteinsdottir U, Samani N, Gudmundsson G, Grant S, Thorgeirsson G, Sveinbjornsdottir S, Valdimarsson E, Matthiasson S, Johannsson $H$, Gudmundsdottir O, Gurney M, Sainz J, Thorhallsdottir M, Andresdottir M, Frigge M, Topol E, Kong A, Gudnason V, Hakonarson H, Gulcher J, Stefansson K. The gene encoding 5 -lipoxygenase activating protein confers risk of myocardial infarction and stroke. Nat Genet 2004;36:233-9

37 Milunsky A, Neurath PW. Diabetes mellitus in Down's Syndrome. Arch Environ Health 1968;17:372-6.

38 Jeremiah DE, Leyshon GE, Rose T, Francis HW, Elliott RW. Down's syndrome and diabetes. Psychol Med 1973;3:455-7.

39 Van-Goor JC, Massa GG, Hirasing R. Increased incidence and prevalence of diabetes mellitus in Down's syndrome. Arch Dis Child 1997;77:186-PY.

40 Burch PR, Milunsky A. Early-onset diabetes mellitus in the general and Down's syndrome populations. Genetics, aetiology, and pathogenesis. Lancet 1969:i:554-8.

41 Amano K, Sago H, Uchikawa C, Suzuki T, Kotliarova S, Nukina N, Epstein C, Yamakawa K. Dosage-dependent over-expression of genes in the trisomic region of Ts $1 \mathrm{Cje}$ mouse model for Down syndrome. Hum Mol Genet 2004; 13:1333-40.

42 Gretarsdottir S, Sveinbjornsdottir S, Jonsson H, Jakobsson F, Einarsdottir E, Agnarsson U, Shkolny D, Einarsson G, Gudjonsdottir H, Valdimarsson E, Einarsson O, Thorgeirsson G, Hadzik R, Jonsdottir S, Reynisdottir S, Bjarnadottir S, Gudmundsdottir T, Gudlaugsdottir G, Gill R, Lindpaintner K, Sainz J, Hannesson H, Sigurdsson G, Frigge M, Kong A, Gudnason V, Stefansson K, Gulcher J. Localization of a susceptibility gene for common forms of stroke to 5q12. Am J Hum Genet 2002;70:593-603.

43 Tsukahara F, Hattori M, Muraki T, Sakaki Y. Identification and cloning of a novel cDNA belonging to tetratricopeptide repeat gene family from Down syndrome-critical region 21q22.2. J Biochem (Tokyo) 1996;120:820-7.

44 Fingerlin T, Boehnke $M$, Abecasis $G$. Increasing the power and efficiency of disease-marker case-control association studies through use of allele-sharing information. Am J Hum Genet 2004;74:432-43.

45 Horikawa Y, Oda N, Cox NJ, Li XQ, Orho-Melander M, Hara M, Hinokio Y, Lindner TH, Mashima H, Schwarz PEH, del-Bosque-Plata L, Horikawa Y, Oda Y, Yoshiuchi I, Colilla S, Polonsky KS, Wei S, Concannon P, Iwasaki N Schulze T, Baier L, Bogardus C, Groop L, Boerwinkle E, Hanis CL, Bell Gl.
Genetic variation in the gene encoding calpain-10 is associated with type 2 diabetes mellitus. Nature Genet 2000:26:163-75.

46 Patil N, Berno AJ, Hinds DA, Barrett WA, Doshi JM, C. R. H, Kautzer CR, Lee DH, Marjoribanks C, McDonough DP, Nguyen BTN, Norris MC, Sheehan JB, Shen N, Stern D, Stokowski RP, Thomas DJ, Trulson MO, Vyas KR, Frazer KA, Fodor SPA, Cox DR. Blocks of limited haplotype diversity revealed by highresolution scanning of human chromosome 21 . Science 2001;294:1719-23.

47 Olivier M, Bustos VI, Levy MR, Smick GA, Moreno I, Bushard JM,

Almendras AA, Sheppard K, Zierten DL, Aggarwal A, Carlson CS, Foster BD, Vo N, Kelly L, Liu X, Cox DR. Complex high-resolution linkage disequilibrium and haplotype patterns of single-nucleotide polymorphisms in $2.5 \mathrm{Mb}$ of sequence on human chromosome 21. Genomics 2001;78:64-72.

48 Nithiyananthan R, Heward JM, Allahabadia A, Barnett AH, Franklyn JA, Gough SCL. A heterozygous deletion of the autoimmune regulator (AIRE1) gene, autoimmune thyroid disease, and type 1 diabetes: No evidence for association. J Clin Endocrinol Metab 2000;85:1320-2.

49 Shield JPH, Wadsworth EJK, Hassold TJ, Judis LA, Jacobs PA. Is disomic homozygosity at the APECED locus the cause of increased autoimmunity in Down's syndrome? Arch Dis Child 1999:81:147-50.

50 Robbins MJ, Sharp RA, Slonim AE, Burr IM. Protection against streptozotocininduced diabetes by superoxide dismutase. Diabetolog 1980;18:55-8.

51 Oberley LW. Free radicals and diabetes. Free Radic Biol Med 1988;5:113-24.

52 Fischer LJ, Hamburger SA. Inhibition of alloxan action in isolated pancreatic islets by superoxide dismutase, catalase, and a metal chelator. Diabetes 1980;29:213-16

53 Kubisch HM, Wang J, Bray TM, Phillips JP. Targeted overexpression of Cu/Zn superoxide dismutase protects pancreatic beta-cells against oxidative stress. Diabetes 1997:46:1563-6.

54 Eizirik DL, Sandler S. Function and metabolism of pancreatic beta-cells maintained in culture following experimentally induced damage. Pharmacol Toxicol 1989;65:163-8.

55 Nielsen C, Hansen D, Husby S, Jacobsen BB, Lillevang ST. Association of a putative regulatory polymorphism in the PD-1 gene with susceptibility to type 1 diabetes. Tissue Antigens 2003;62:492-7.

56 Hug BA, Ahmed N, Robbins JA, Lazar MA. A chromatin immunoprecipitation screen reveals protein kinase $\mathrm{C}$ beta as a direct RUNX1 target gene. J Biol Chem 2004;279:825-30.

57 Ardlie KG, Kruglyak L, Seielstad M. Patterns of linkage disequilibrium in the human genome. Nat Rev Genet 2002;3:299-309.

58 Tabor HK, Risch NJ, Myers RM. Opinion: Candidate-gene approaches for studying complex genetic traits: practical considerations. Nat Rev Genet 2002;3:391-7. 